\title{
Review
}

\section{The Role of the Renin-Angiotensin System in Cardiovascular Disease}

\author{
Michael Bader, Jürgen Wagner, MinAe Lee, and Detlev Ganten
}

\begin{abstract}
Recent findings have increased our understanding of the role of the renin-angiotensin system in cardiovascular diseases. This was possible by the progress made in molecular biology and the import of this methodology into cardiovascular research by several groups in the past few years. Studies by these groups accumulated evidence especially for the existence and physiological importance of organ-based renin-angiotensin systems and their involvement in the pathogenesis of hypertension and the accompanying disorders of the heart, the kidney, and the vessels. This Review will focus mainly on the relevance of the local renin-angiotensin systems for cardiovascular diseases and the value of transgenic animals as models to analyse these systems (Hypertens Res 1994; 17: 1-16).
\end{abstract}

Key Words: renin-angiotensin system, kidney, heart, antihypertensive treatment, essential hypertension

It has long been known that the renin-angiotensin system (RAS) plays an integral role in the regulation of blood pressure as well as in electrolyte and body fluid balance. In its classical definition, the RAS maintains blood pressure via the effector peptide angiotensin II (ANG II) generated within the circulation in an enzymatic cascade initiated by renin, which is secreted by the juxtaglomerular cells of the kidney. Renin cleaves angiotensinogen (AOGEN) derived from the liver yielding the inactive decapeptide ANG I, which in turn is activated proteolytically by the endothelium-associated angiotensin-converting enzyme (ACE) to yield the octapeptide ANG II. ANG II increases blood pressure in several ways, i.e., vasoconstriction, stimulation of aldosterone secretion in the adrenal gland, sodium retention in the kidney and intestine, and upregulation of the sympathetic tone.

Furthermore, degradation products of ANG I and ANG II like ANG (1-7), ANG III, or ANG IV have been shown to elicit biological effects (1-3) but the in vivo significance of these peptides still awaits clarification. All angiotensin peptides can be produced from the sole precursor AOGEN also by enzymatic reactions beyond the classical RAS. One important example is the chymase present in human hearts partially replacing the function of ACE (4). The relevance of these metabolic pathways, however, is still enigmatic.

The importance of the RAS goes far beyond blood pressure regulation and includes the whole cardiovascular homeostasis. This is proven by the therapeutic value of drugs interfering with this system like ACE-inhibitors (CEI) and the newly developed ANG II receptor antagonists and renin in- hibitors. Furthermore, genetic studies in rats and humans have shown that particular alleles of the AOGEN and the ACE gene are linked to hypertension (5-7) and myocardial infarction ( 8$)$. It has been postulated that ANG II is active on the cellular level, exerting paracrine or even autocrine actions (9). In addition, it was demonstrated that ANG II biosynthesis can occur in the tissues themselves, leading to the concept of organ-based, local RAS $(10,11)$. The functionality of these systems has been established in a number of tissues such as the kidney, adrenal gland, brain, heart and vasculature. Evidence that these tissue RAS may act independently of the plasma system can be found in numerous studies investigating the chronic effects of CEI on blood pressure (12). The reports demonstrated that the antihypertensive effects of these substances were predominantly correlated to inhibition of $\mathrm{ACE}$ in the tissues and not in the plasma.

The investigation of the RAS in humans has limitations for practical and ethical reasons. Most of these studies have been confined to the measurement of the plasma components of the RAS and their response to physiological and pathophysiological stimuli. With the evolving concept of local RAS, the investigation of the tissue-specific gene expression of its components has become increasingly important. The opportunities to study the action of these genes in humans are rare, since viable human tissue in only accessible from surgery specimens (13) or biopsy samples (14), which provide only very small amounts of tissue. To overcome this setback, animal models with genetic hypertension have successfully been developed e.g. the spontaneously hypertensive rat (SHR) and

From the Max-Delbrück-Center for Molecular Medicine (MDC), Berlin-Buch, Germany.

Address for Reprints: Michael Bader, Ph.D., Max-Delbrück-Center for Molecular Medicine (MDC), Robert-Rössle-Str. 10, D-13125 Berlin-Buch, FRG.

Received February 10, 1994. 
transgenic rats like TGR (mREN2) 27 (15), which show characteristics similar to human hypertension (16). In addition, it was possible by transgenic techniques to express the human RAS in rats by the production of TGR (hREN) and TGR (hAOGEN), rats harbouring the human genes for renin and AOGEN, respectively (17). These animals for the first time allow experimental studies on the human RAS.

\section{Local Renin-Angiotensin Systems}

To support the existence of independently expressed and regulated tissue RAS it is necessary to demonstrate the local synthesis of the components, renin, AOGEN, and ACE and the presence of functioning ANG II receptors. In addition, the synthesis of these proteins should be regulated independently of the circulating RAS. These criteria are met in several tissues, e.g., brain, adrenal gland, heart, and vessels, where the mRNA for renin, AOGEN, $\mathrm{ACE}$, and ANG II receptors have been shown to be regulated by physiological or pharmacological effectors $(18-27)$. The relevance of these systems is confirmed by the fact that chronic treatment with CEI failed to correlate with pretreatment plasma renin activity but did correlate with sustained inhibition of ACE-activity in the kidney (28). Thus, there is evidence that besides the circulating endocrine RAS there are several tissue RAS serving para-, auto- or intracrine functions.

\section{Kidney}

The kidney is the major renin secreting organ of the body. Bilateral nephrectomy results in the disappearance of active renin from the plasma and in a substantial decline in circulating prorenin (29). However, the demonstration of renal gene expression of renin, AOGEN and ACE points towards the existence of an intrarenal RAS regulating intrarenal hemodynamics and sodium homeostasis.

Using immunocytochemical techniques, renin protein in the kidney has been localized in afferent and efferent arteriolar juxtaglomerular cells, interlobular arteries as well as in proximal, connecting and cortical collecting tubules in lower quantities (30-32). Since these methods do not differentiate between uptake from blood and local synthesis, in-situ-hybridization has been applied, confirming in mature rodents and humans the juxtaglomerular apparatus as the principal locus of renal renin mRNA-expression $(33,34)$. A low expression of renin is detected in the mesangium, other vascular structures, and in proximal tubular cells. However, during ontogeny, renin expression varies with ongoing maturation. In tissue sections of rat fetal kidney renin mRNA is detected in the vascular pole of juxtamedullary nephrons and afferent, interlobular and arcuate arteries. In newborns, expression in the latter two locations disappears and finally in adult animals, renin mRNA is restricted to the juxtaglomerular apparatus (35). The ontogenetic pattern of renin gene expression is paralleled by a 10 - to 20 -fold decrease in the amount of renal renin mRNA from fetal through newborn to adult stages $(35,36)$. The role of renovascular renin in ontogeny is unclear but may be related to the possible effect of ANG II on angiogenesis (37). Within the cells of the juxtaglomerular apparatus renin is stored in vesicles and may be intracellularly activated to active renin or also be sequestered as inactive prorenin.

Albeit in adulthood, renin expression is confined to the juxtaglomerular apparatus in the basal state, vascular smooth muscle cells, extending along the afferent arteriole may be "recruited" to express renin in response to various pharmacological and physiological stimuli $(38,39)$. Thereby, an increase in renal renin mRNA may be due to an increase in the number of renin-producing cells rather than in renin synthesis per cell as shown in isolated renal microvessels $(40)$. Stimulation of renal renin mRNA content with recruitment of renin producing cells is induced by treatment with CEI $(39,41,42)$. CEI enhance renal renin expression probably by the interruption of the negative feedback inhibition of renin synthesis exerted by ANG II (43). Different CEI strongly vary in their potency to raise renal renin mRNA-expression. In a study by Keuneke et al. (44) using SHR, lisinopril elicited a much higher increase in renal renin gene expression than captopril or quinapril given in equidepressor doses. This may be related to differences in tissue-availability of the individual CEI. In contrast to that, renin inhibitors such as ES 1005 are reported to suppress renal renin gene expression in marmosets (45). Other stimuli eliciting intrarenal renin synthesis comprise sodium-depletion $(41,46,47), \beta$-adrenoreceptor activation (48), adrenalectomy (41), dietary protein (49, 50, J.W., unpublished observations) or renal nerve stimulation and ureteral obstruction $(51,52)$. Although all these factors enhance renal renin expression, their effect on plasma renin activity and prorenin is differential. Sodium-depletion (53) and dietary protein $(54,55)$ raise plasma renin activity. In contrast, ureteral obstruction only alters prorenin but not plasma renin activity $(51,56)$. Only few data are available, if the increase in renal renin content is due to enhanced gene transcription, to the rate of degradation, or changes in the proportions of renin mRNA to other RNAs. Furthermore, the increase in renal renin mRNA in sodium-depletion does not correspond in a linear fashion to changes in renal renin protein or active renin secreted from the kidney into the plasma (53) indicating posttranscriptional events.

AOGEN protein has been demonstrated first in granules isolated from the kidney cortex (57) and could then be localized to the proximal tubular brush border by immunocytochemistry (58). Local synthesis was suggested by its disappearance after protein synthesis inhibition (59) and confirmed by the detection of the mRNA $(46,60-63)$ and the demonstration of its specific regulation by sodium (46, 64), androgens (65) but not by CEI (38). In situ hybridization revealed that its expression is confined to the proximal convoluted tubule (34) and it could be shown that primary cells obtained from this area are capable to produce AOGEN (66). 
ACE is present in high amounts in kidney tissue (67-69) where it is located in blood vessels and in the brush border and basolateral membrane of proximal tubular cells $(70-77)$.

Receptors for ANG II, mostly of the $\mathrm{AT}_{1}$ subtype (78) and its mRNA $(24,25)$, have been decribed in the kidney $(79,80)$. They are localized on the mesangial cells and the basement membranes of the glomeruli, the tubular brush border and basolateral membranes and in the inner stripe of the outer medulla, where they are confined to the interstitial cells $(81-87)$.

It was hypothesized that these RAS-components act together to regulate the sodium and water balance of the organism first intrarenally and only if this is not sufficient renin is released into the circulation and activates aldosterone secretion from the adrenal (88). After a decrease in the distal tubular sodium, chloride load, or fluid flow rate, the macula densa emits a signal, possibly nitric oxide (89), eliciting the release of renin from the juxtaglomerular cells into the lumen of the afferent arteriole and into the interstitium $(32,90-95)$. From the latter site, it diffusses to the anatomically close proximal tubular epithelium. There, high amounts of AOGEN and ACE are present and allow the generation of high local concentrations of ANG II (94, 96 , 97) which is a potent stimulator of sodium absorption (98-103), hydrogen ion secretion followed by bicarbonate absorption $(104,105)$, and ammonia production $(106,107)$ in this part of the nephron. In addition, the renin released into the glomerular blood stream together with systemic AOGEN and endothelial ACE, forms ANG II, which contracts mesangial cells and the efferent arteriole thereby increasing the glomerular ultrafiltration coefficient $(102,108-113)$.

Furthermore, ANG II increases sodium reabsorption by a reduction of renal papillary blood flow probably elicited via contraction of the medullary interstitial cells $(87,114)$. The systemic circulation is protected from these fluctuations of ANG II concentrations by a very efficient clearing mechanism exerted by the kidney itself $(115-117)$ leading to ANG II levels in the renal vein which are not higher than in the extrarenal plasma.

Locally produced ANG II may also be involved in adaptive processes during hypertension, heart failure and renal diseases accompanied by a reduction of renal mass. It induces hypertrophy of proximal tubular cells $(118,119)$, renal vascular smooth muscle and interstitial cells, accompanied by an increase in collagen deposition $(120,121)$. If being elicited inappropriately, these beneficial effects may injure the kidney leading to vascular lesions, interstitial fibrosis, and finally glomerular sclerosis. Evidence for these mechanisms is provided by experiments showing the positive effects of CEI and ANG II receptor antagonists on the progression of these diseases in animal models $(122,123)$ and patients, e.g. with diabetic nephropathy $(124-127)$. The deleterious implications of a high protein diet in some renal diseases might also be transmitted via an increased activity of the intrarenal $\operatorname{RAS}(50,128)$.
Furthermore, the chronic state of heart failure is associated with changes in renal function. It has been demonstrated that rats with mild heart failure do not respond to volume loading with an increased urinary excretion. Ichikawa et al. (129) found a decreased glomerular filtration rate in single nephrons and an increased perfusion resistance in rats suffering from heart failure. Although plasma level of renin and ANG II were within normal levels perfusion resistance and single nephron GFR were normalized after local administration of CEI into the renal artery, whereas in control rats no change of renal function was observed following administration of CEI. It has also been demonstrated that renal AOGEN mRNA levels were increased in rats with heart failure following experimental myocardial infarction (130). There was a positive correlation between the size of the infarction, which reflects the severity of heart failure and renal AOGEN mRNA, whereas transcript levels in the liver representing the main site of AOGEN production remained unchanged. The decrease in blood pressure after chronic administration of CEI correlated with renal ACE inhibition and not with ACE activity in the plasma $(28,131,132)$. It was also shown that an increase of renal AOGEN mRNA in rats with heart failure was prevented by CEI (28).

Involvement of renal renin in hypertension: renal artery stenosis is the most pertinent example of renin-dependent secondary hypertension. In two kidney, one clip hypertension renal renin mRNA levels rise 4- to 6-fold in the clipped kidney whereas in the contralateral kidney renin mRNA is suppressed $(133,134)$. In the early phase of Goldblatt hypertension the increase in renal renin mRNA is paralleled by an elevation in plasma active renin, whereas in the chronic phase conflicting results are reported showing high or normal levels of renal renin and plasma renin and angiotensin levels (133, 135). The activation of local renin synthesis in the clipped kidney raises glomerular capillary hydraulic pressure and maintains glomerular filtration. This explains the episodes of acute renal failure induced by CEI in patients with bilateral renal artery stenosis or solitary kidneys (136). Intrarenal "Goldblatt" mechanisms with induction of renal renin synthesis due to structural vascular alterations and local ischemia have been implicated in the high prevalence of hypertension in renoparenchymatous diseases. In other forms of hypertension, which are not characterized by elevated plasma active renin levels, renin gene expression is also modulated in the kidneys. SHR exhibit a decrease in renal renin mRNA with the development of hypertension in comparison to age-matched Wistar-Kyoto (WKY) controls (137). However, stimulation by sodium-depletion or CEI caused a greater increase in renal renin gene expression in SHR than in WKY-rats even though no differences in plasma renin activity were noted (138). How these abnormalities in renal renin gene expression relate to the pathogenesis of hypertension in this models has not been clarified yet. Transgenic animal studies using gene constructs suitable to activate or deactive local RAS in a 
tissue-specific manner may be required to delineate the contribution of renal renin to hypertension.

\section{Heart}

The heart is one of the most sensitive target organs to the actions of ANG II. As the local production of AOGEN $(22,60,139-141)$, renin $(22,142-144)$ and ACE $(14,23)$ mRNA, as well as the presence of ANG II receptors (145-148) was confirmed in rat and human myocardium, the existence of a local RAS in the heart was postulated (149-151).

The positive inotropic effect of ANG II was reported by several investigators (152). To distinguish between direct and indirect effects, which are primarily due to the modulation of the sympathetic nervous system, investigations applying $\beta$-adrenoceptor blockers (152-155), extrinsic cardiac denervation $(147,156)$, isolated cardiomyocyte preparations $(157,158)$, or isolated perfused hearts $(159$, 160) were performed. On the molecular level the inotropic effects of ANG II are apparently mediated by its influence of calcium homeostasis and transmembranous conductance. Several studies (155, 161) showed that ANG II changed the plateau phase of the cardiac action potential increasing its height and duration and leading to a rise in peak developed tension.

Moreover, ANG II may be involved in the development of cardiac hypertrophy. CEI prevent or decrease cardiac hypertrophy in animals $(162,163)$ and humans $(164,165)$ but these effects are accompanied by a change in the systemic hemodynamics. Several authors have studied the regulation of the cardiac RAS in left ventricular hypertrophy due to aortic banding. It has been demonstrated that aortic coarctation results in a significant upregulation of AOGEN and renin mRNA in the left ventricle, whereas no correlation existed with plasma renin levels which were only transiently increased after the constriction $(166,167)$. In addition, it has been demonstrated that ACE mRNA and the intracardiac conversion of ANG I to ANG II are increased in the presence of established pressure overload hypertrophy of the left ventricle of rat hearts (168).

Several studies have been performed in order to test the effect of CEI on left ventricular hypertrophy. ACE inhibition in experimental aortic banding significantly reduces and causes regression of left ventricular hypertrophy (169), even at subdepressoric doses (170). In addition, after enalapril treatment, an upregulation of AOGEN and renin gene expression has been reported (166) suggesting a negative feedback of ANG II on the pathway. Furthermore, other models of left ventricular hypertrophy, like SHR or isoproterenol-infused rats, respond very sensitive to CEI by a reduction in left ventricular weight accompanied by a regression in myocardial fibrosis (171-174). These changes were not correlated with blood pressure reduction or plasma ANG II levels but with a fall in cardiac ANG II concentrations $(173,174)$.

The possible implication of the cardiac RAS has also been studied in experimental heart failure. Some authors have reported a transient increase of
AOGEN mRNA in myocardial infarction and failure (175). A doubling of AOGEN gene expression as compared to control rats has been described in ventricular myocardium during cardiac chronic tachipacing (176). In chronic heart failure induced by ligation of the left coronary artery in rats an enhancement of ACE mRNA was found, which correlated with the cardiac ACE activity, but not with its activity in other organs (177).

Therefore, the cardioprotective effects of CEI in the acutely ischemic or infarcted myocardium are not surprising. Studies on isolated heart preparations (159) demonstrated the prevention of postischemic dysrhythmias as well as improvement of coronary flow and ventricular function by administration of CEI. In this experimental model, intracardiac hormonal systems such as the RAS and the bradykinin system can be studied exclusively. Moreover, data demonstrating a reduction in infarction size after coronary artery ligation in dogs, treated with CEI (178), show that the area at risk and the infarcted region were smaller than expected from the finding that CEI improve the coronary flow. This effect may be due to an interaction with the myocardial angiotensin metabolism but also bradykinin seems to be involved, as this reduction was abolished by a bradykinin antagonist (160).

Several studies $(159,160,179-182)$ demonstrated that CEI reduce the incidence and mean duration of malignant arrhythmias. This effect could be blunted by ANG II and bradykinin inhibitors, but not by ANG I. In addition, the observed reduction of norephinephrine overflow in ischemic hearts may be the result of an interaction between ANG II and the sympathetic nervous system.

An additional pathophysiological aspect in the postischemic phase of acute ischemia is the "stunned" myocardium. This phenomenon is defined as a transient contractile dysfunction in the peri-infarction area. Morphological changes appear in the extracellular collagen matrix connecting the cardiac myocytes. These may be elicited by collagenases activated by oxygen-derived free radicals, which are increasingly produced during reperfusion. The preservation of the intercellular collagen by some CEI may be caused by the free radical scavenging properties of the sulfhydryl group of some of these compounds $(183,184)$.

The pathomorphological changes after myocardial infarction are described in the term "ventricular remodeling" leading to progressive ventricular dilatation and eventually to pump failure. This dilatation is not necessarily associated with an increase of filling pressure, but frequently accompanied by a rightshift of the ventricular pressure-volume curve characteristic of a volume overload hypertrophy $(185,186)$. Histologically the ventricular remodeling appears as hypertrophy accompanied with a side-toside slippage of the myocytes, which leads to an increase of the ventricular volume and a maintained or even reduced wall thickness $(187,188)$. In addition, myocardial fibrosis with changes of the extracellular matrix is reported (189). The beneficial effects of CEI consist of a decrease or prevention of 
ventricular remodeling and leads to an improvement of the functional status as well as a reduction of the mortality in animals and in humans (190-192). The fact that CEI, in contrast to other vasodilators, prevent ventricular remodeling (192) may be caused by their direct influence on the local tissue RAS.

The results of the animal studies may not necessarily be applicable to the human system, e.g., because of the presence of chymase, an ANG II generating enzyme not influenced by CEI (see above). Clinical trials of CEI enrolling patients with left ventricular dysfunction mostly after myocardial infarction gave controversial results $(191,193-198)$. Probably, the benefit of ACE inhibitors is dependent on the onset of treatment (197) and on the particular drug used as captopril with its sulfhydryl group in contrast to enalapril seems to have effects additional to the inhibition of the RAS, i.e the scavenging of free radicals (see above). Early functions of systemic or locally produced $A N G$ II in healing and adaptive growth response processes after myocardial infarction may be beneficial but if acting longterm may promote ventricular dilatation (191).

However, the importance of ACE already in the etiology of myocardial infarction is corroborated by a genetic study revealing specific allels of this gene as risk factors for the disease in humans (8). The physiological causes for that, however, are still elusive and might imply the bradykinin system besides the local or the systemic RAS.

\section{Vasculature}

It is well known that chronic hypertension induces secondary structural changes of the vascular wall leading to an enhanced vasoconstrictor response to vasoactive substances such as ANG II. The activation of vascular smooth muscle cells by ANG II leads to the formation of two second messengers, inositol triphosphate (IP3) and diacylglycerol. IP3 rapidly mobilizes free calcium and thus initiates the calcium dependent and calmodulin activated phosphorylation of the myosin light chain resulting in cellular contraction, whereas diacylglycerol via protein kinase $\mathrm{C}$ is responsible for sustained tonic effects of vascular smooth muscle cells (199).

Since several autocrine- paracrine acting substances are generated in the vessel wall such as endothelin-1 or nitric oxide it was suggested that vascular ANG II may also exert paracrine functions. Biochemical and immunhistochemical studies revealed renin, $\mathrm{AOGEN}$ and $\mathrm{ACE}$ in the vasculature. Renin-like activity was found early in vessel homogenates (200). Interest in vascular renin was revived when renin-like activity in some resistance vessels was shown to persist up to 12 days after bilateral nephrectomy in dialyzed dogs (201). Vascular renin even increased in these nephrectomized animals following hemorrhage, as did plasma renin. Others found that renin in aortic wall has a much more prolonged half-life than plasma renin but decreases after total nephrectomy (202). However the presence of renin mRNA in vascular tissue is still a matter of debate. One report indicated the expres- sion of the renin gene in aortic tissue (21), while this was not confirmed in other studies $(203,204)$.

The mRNA for AOGEN was detected in the media and adventitia of the rat aorta $(205,206)$. ACE mRNA was found in human aorta, saphenous vein as well as in the umbilical vein (23). In SHR, ACE activity in aorta, brachial and mesenteric vessels as well as in the portal vein was higher as compared to normotensive WKY, whereas plasma ACE activity in SHR was lower than in WKY (207). In cut strips of arteries from dogs contraction was induced following administration of ANG I. This effect was suppressed by CEI or ANG II antagonists (208). In addition, Andre et al. demonstrated that aortic smooth muscle cells are able to convert ANG I to ANG II (209). ANG II receptors are also expressed in the vasculature, and recent data have established the existence of the ANG II type 1 receptor mRNA in this tissue (25).

The components of the vascular RAS interact to form ANG I and II: Isolated perfused vascular beds release considerable amounts of these peptides $(210-212)$. This release is greatly inhibited by CEI and stimulated by the perfusion with AOGEN or renin $(212,213)$. Angiotensin release and metabolism may be under regulatory influence of $\beta$ adrenergic tone (214) and adenosine (215) and may vary in different models of experimental hypertension $(213,216)$. More than half of ANG I during a single pass through a bloodless perfusion system is converted to ANG II of which about $50 \%$ is degraded or taken up (212). Furthermore, comparable results were obtained in CEI-treated humans infused with radiolabelled ANG I. At least half of the venous ANG I level was produced in the vasculature of these volunteers. Again, about $50 \%$ of arterial ANG I was taken up or degraded in the vasculature of the lower limbs during one circulation (217).

These findings confirm the hypothesis of an autocrine-paracrine regulated RAS, which may be involved in the regulation of vessel tone as well as in the development of adaptive changes secondary to hypertension. What is the evidence that the RAS has such functions in the vasculature in vivo? The trophic actions of ANG II were first described by Schelling et al. (218), who found that ANG II increased the cell number of cultured mouse fibroblasts. The effect was dose-dependent and could be blocked by the ANG II receptor antagonist, saralasin. These findings were later confirmed and expanded by other authors (for review see 219, 220). The stimulation of smooth muscle cells in culture by ANG II, however, had somewhat controversial effects. Whereas some authors also described hyperplastic effects of ANG II on vascular smooth muscle cells (221), other studies detected a hypertrophic response only $(222,223)$. This apparent discrepancy can possibly be explained by species variability and differences in the experimental conditions.

Further evidence that ANG II is involved in growth phenomena can be derived from experiments showing its stimulatory effect on protooncogenes in vascular smooth muscle cells. These 
genes play a role in the development of the cardiovascular structure and are normally not expressed in mature cells but can be expressed again under pathological conditions such as cardiovascular hypertrophy (224). Indeed, several investigators $(205,225-228)$ were able to demonstrate that the peptide increased the expression of the protooncogenes c-fos, c-myc, c-jun as well as of the platelet derived growth factor (PDGF) in a dose-dependent manner. The direct link between ANG II and the hypertrophic changes was clearly demonstrated by experiments showing that antisense inhibition of $c$-fos (229) or PDGF (230) was able to block the stimulating effects of ANG II on DNA and protein synthesis in smooth muscle cells. Despite this, it should be pointed out that the studies were performed in cultured cells, and it remains to be determined whether or not there is an interaction between ANG II and proto-oncogene activation in vivo and in hypertension. The growth-promoting action is further supported by the recent finding that ACE-inhibition and ANG II receptor blockade blunts and ANG II infusion stimulates vascular smooth muscle proliferation after myointimal injury with a balloon catheter (231-236). However, a controversy exists which ANG II receptor subtype mediates these actions: While the growth-promoting effects on cultured vascular smooth muscle cells are inhibited by the $\mathrm{AT}_{1}$-antagonist DuP753 (losartan) $(237,238)$, the neointima formation is blocked by the $\mathrm{AT}_{2}$-specific drug CG42112A (236). The relevance of vascular ANG II production for the vascular hypertrophy accompanying hypertension and the mechanisms involved is still a matter of intensive research (239-241).

\section{Transgenic Animals}

A way to discriminate the effects caused by the RAS from those by other peptide systems is to modulate its activity exclusively by incorporating the gene of one of its components into the genome of a normal animal, i.e., to produce a transgenic mouse or rat with one of the genes of the RAS. These animals enable investigators to study the effects of a single additional gene via a dysregulated RAS on the cardiovascular system. This is especially interesting when the gene is derived from humans in whom studies about the physiological effects of the RAS are difficult to perform. In addition, these animal model systems allow the testing of drugs that specifically interfere with the RAS like ANG II receptor antagonists and renin inhibitors, which are currently under intensive investigation. Two recently developed transgenic rat strains are described in the following sections.

\section{TGR (mREN2) 27}

The introduction of the Ren-2 gene of the DBA/2 mouse into the genome of rats by microinjection techniques has led to the generation of the transgenic rat model TGR (mREN2) 27 (15). These rats develop fulminant hypertension, beginning at 4 weeks and reaching a maximum at 9 weeks of age.
The Ren-2 transgene in TGR (mREN2) 27 is expressed most abundantly in adrenal gland followed by thymus, intestine, fat, female and male genital tract, kidney, brain, and pituitary (242-244). In adrenal gland, the expression pattern resembled that of female DBA/2 mice (245) as renin mRNA was found in two separate layers, the innermost region of the zona glomerulosa together with the outer zona fasciculata and patches of cells in the zona reticularis bordering the medulla (246). In a nontransgenic rat adrenal gland, renin gene expression is barely detectable indicating that the signal in TGR (mREN2) 27 is mainly derived from Ren-2 transcripts. Tissue renin protein concentrations correspond to the mRNA measurements in being low in kidney and enhanced in adrenal gland indicating that the transgene mRNA is accurately translated (15).

These striking pecularities of transgene expression have consequences for the physiology of TGR (mREN2) 27. Having in mind the decreased renin gene expression in the kidney, it is not surprising, that active renin concentration in the plasma of TGR (mREN2) 27 is lower than in control animals $(15,247)$. The same was true for nearly all other parameters of the RAS, like ANG I, ANG II and AOGEN, but not for prorenin. This precursor is highly enriched in plasma reaching more than 20 fold higher levels than in Sprague-Dawley (SD)rats. Most probably, it is mainly derived from the adrenal glands as its concentration is lowered down to about $20 \%$ by bilateral adrenalectomy (246). In addition, it could be shown that isolated adrenal cells from TGR (mREN2) 27 secrete considerable amounts of active renin and prorenin (248). The physiological relevance of the high plasma prorenin levels especially in the development of hypertension is still subject of research. The fact, that blood pressure was reduced to nearly normotensive values after adrenalectomy (246) does not prove a causal relationship of transgene expression and prorenin secretion in the adrenal gland with the high blood pressure, as it can also be explained by the total elimination of steroid production.

ANG II is well known as stimulator of aldosterone synthesis in the adrenal gland $(249,250)$. With the concept of local acting tissue RAS also in the adrenal gland (251-258), the enhanced renin gene expression and activity in this organ of the transgenic rats may lead to an increased level of ANG II and in turn to an elevation of steroid, especially aldosterone, secretion. While adult hypertensive animals did not corroborate this hypothesis exhibiting only insignificantly increased urinary steroid concentrations (259) the excretion of deoxycorticosterone, corticosterone, and aldosterone was elevated in young animals during the development of hypertension 1.5 to 2.5 -fold compared with SD-rats (259). When the animals were treated with adrenocorticotropic hormone (ACTH), their urinary corticosterone excretion increased more pronounced than in SD-rats (259). In addition, the already very abundant plasma prorenin was further enhanced about 10 -fold by this treatment (259). These data 
indicate that there is an intimate interplay between ACTH, the intraadrenal RAS and steroid production by the adrenocortical cells in TGR (mREN2) 27. These interactions were studied in more detail in vitro with adrenal cells isolated from transgenic rat adrenals (248). They may well be relevant for the development of hypertension, however not, as one would expect, by the elevated mineralocorticoid levels, as the mineralocorticoid receptor antagonist spironolactone did not lower blood pressure in young TGR (mREN2) 27 (243). But the stimulated adrenal RAS is most probably involved in this process, as high dose dexamethasone treatment inhibiting ACTH and thereby adrenal steroid production blocks blood pressure elevation in young TGR (mREN2) 27 significantly (260). In contrast, the same dose of dexamethasone has a marked hypertensinogenic effect in adult SD-rats. In addition and in agreement with the ACTH experiment described above, prorenin in the plasma of TGR (mREN2) 27 is markedly downregulated by this treatment.

Taken together these data argue in favor of a causal effect of a stimulated adrenal RAS in the development of hypertension, however, via an up to now unknown mechanism including prorenin or steroids lacking mineralocorticoid action.

Interestingly, TGR (mREN2) 27 exhibit pronounced morphological alterations in kidney, heart, and vessels in the adult stage (246). In kidney, glomerular damage is evident which finally culminates in glomerulosclerosis being often the cause of early death especially in homozygous animals. The observed pathologies resemble tightly other experimental hypertension models and human disease states. Thus, TGR (mREN2) 27 represents a valid model for the secondary effects of sustained hypertension on the kidney morphology.

The same holds true for the cardiovascular alterations. The hearts and particularly their left ventricles are hypertrophied and focal perivascular fibrosis of the coronary arteries could be observed (246, 247). These and other muscular type arteries of the body including aorta exhibited an increased thickness of the tunica media based on the hypertrophy of vascular myocytes and a massive neogenesis of connective tissue matrix (247). As vessels exhibited detectable Ren-2 gene expression in TGR (mREN2) 27 (247) an activated local tissue RAS in the vascular wall (see above) could be responsible for the hypertrophic effects. In support of this, it was observed that isolated perfused hindlimbs of the transgenic rats produce significant amounts of active renin (261).

As hypertension in TGR (mREN2) 27 is based on the expression of an additional renin gene in several tissues, CEI should have a marked antihypertensive effect. Indeed, Captopril $(10 \mathrm{mg} / \mathrm{kg}$ body weight per day) lowered blood pressure of heterozygous (15) and homozygous (243) animals significantly after two weeks of treatment. Lisinopril turned out to be even more active in decreasing blood pressure markedly already at a dose of 0.5 $\mathrm{mg} / \mathrm{kg}$ per day and normalising it with 2 and $10 \mathrm{mg} /$ $\mathrm{kg}$ per day (262). This decrease in mean arterial pressure is accompanied by an increase in active plasma renin and renin gene expression in kidney affecting both, the Ren-2 transgene and the rat renin gene (262). This, again, shows that the depressed renin gene expression in the kidney is caused by either the high blood pressure or a negative feedback of ANG II based on an overactive intrarenal RAS. Preliminary data showing that the vasodilator Hydralazin reduces blood pressure without affecting renin gene expression in the kidney argue in favor of the latter hypothesis (M.L., unpublished observations)

CEI also influence the bradykinin system. In order to convincingly show that their inhibitory effect on ANG II synthesis is decisive, we treated the animals with the ANG II receptor type I antagonist losartan (243). Already $0.5 \mathrm{mg} / \mathrm{kg}$ per day had a slight blood pressure lowering effect and 10 $\mathrm{mg} / \mathrm{kg}$ per day normalised it after 4 weeks of treatment. Again, plasma renin activity increased several fold revealing the stimulating effect of the treatment on kidney renin gene expression. Plasma prorenin concentration was not changed indicating that tissue RAS, expecially in the adrenal gland might be regulated differently.

In conclusion, these treatments show that ANG II plays a crucial role in the hypertensinogenic process in TGR (mREN2) 27. Additionally, all available data exclude the plasma RAS as the relevant source of ANG II, but support local RAS in the adrenal gland and possibly other tissues as causative factors for the elevation of blood pressure and the accompanying phenomena. Therefore, TGR (mREN2) 27 is a valuable model to study the specific regulation of these tissue RAS and their role in blood pressure homeostasis, which seems to be more important also for human hypertension than previously thought as it might explain the long-term therapeutic effects of CEI on hypertensive patients (263). In addition, these transgenic rats allow the investigation of the sexual dimorphism in blood pressure observed also in humans. Finally and more basically, TGR (mREN2) 27 can be employed to study the tissue-specific regulation of renin genes.

\section{$T G R(h R E N)$ and TGR (hAOGEN)}

The particular species-specificity of the human renin substrate reaction prevents enzymatical cross-reaction of rat renin with human AOGEN or human renin with rat AOGEN. As a consequence, even though rats are unique models for the investigation of cardiovascular regulation, they cannnot be used for the development and testing of drugs interfering specifically with the human RAS, e.g. renin inhibitors.

In order to study the gene expression of human renin and AOGEN and the species-specific kinetics of the human RAS as a model system for the testing of renin inhibitors, the entire human renin gene containing $3 \mathrm{~kb}$ of the 5'-flanking sequence, $10 \mathrm{ex}-$ ons, 9 introns, and $1.2 \mathrm{~kb}$ of the 3 '-flanking sequence was microinjected into fertilized oocytes of SD-rats (17). From 87 rat eggs implanted, 15 progeny were obtained, of which 5 were found to carry 
the renin transgene. Two of these founder animals, TGR (hREN) 1936 and TGR (hREN) 1988, transmitted the transgene to their offspring, and the line TGR (hREN) 1936 has been bred to homozygosity.

Human renin and prorenin, measured using a human-specific anti-renin antibody, was detected in the plasma of both TGR (hREN) lines. The enzymatic activity of the human renin in rat plasma as measured with a human substrate amounted to 18 ng ANGI/mlxh in TGR (hREN) 1988; this compares with about $1.5 \mathrm{ng} \mathrm{ANGI} / \mathrm{mlxh}$ in human plasma. Rat prorenin, rat renin, ANG I, ANG II, and AOGEN levels were unchanged in TGR (hREN) animals as compared with SD rats, indicating that the human renin did not react with rat angiotensinogen to generate angiotensins. As could be expected, the mean systolic blood pressure in both TGR (hREN) lines was normal $(133 \pm 3 \mathrm{mmHg})$.

To demonstrate the response of human renin to physiological stimuli, TGR (hREN) 1936 animals were sodium depleted, raising their human active renin concentration from $4.8 \mathrm{pg} / \mathrm{ml}$ to $58.3 \mathrm{pg} / \mathrm{ml}$. The rat renin was also stimulated, but there was no difference between animals with or without the transgene. These data clearly indicate that the transgene is transcribed and translated and the protein activated and secreted into the plasma in both lines. The specificity of human renin prevents reaction with the endogenous rat AOGEN, leaving the plasma ANG I and ANG II levels unchanged.

Transgene expression was studied by a human renin-specific RNase-protection assay. A high expression of human renin was found in the kidney, restricted to the juxtaglomerular cells followed by lung, thymus, and gastrointestinal tract in both transgenic lines.

In addition, transgenic rats were produced carrying the human AOGEN gene comprising $1.1 \mathrm{~kb}$ of 5'-flanking sequences, five exons, four introns and $2.4 \mathrm{~kb}$ of 3 '-flanking sequences with an overall size of $16.3 \mathrm{~kb}(17,264)$. From the founder animals which transmitted the transgene to their progeny, one line named TGR (hAOGEN) 1663 expressed and secreted human AOGEN into the plasma at a concentration of $465.3 \pm 44.9 \mathrm{~g} / \mathrm{ml}$ as measured by enzyme-linked immunosorbent assay using a human-specific monoclonal antibody. This exceeds the normal AOGEN levels measured in human plasma (265) as well as in rat plasma by approximately 7 times. The production of human AOGEN in the transgenic rats did not interfere with the level of rat plasma AOGEN, since no significant difference was found between transgenic and non-transgenic littermates.

As a reflection of the species-specificity of human AOGEN, similar levels of ANG II were demonstrated in TGR (hAOGEN) and control animals, indicating that rat renin does not cross-react with human AOGEN even in the presence of excess human substrate to form ANG I. Consequently, TGR (hAOGEN) are normotensive compared to transgene-negative controls.

However, the infusion of recombinant human renin rapidly raised the blood pressure in conscious, unrestrained TGR (hAOGEN) by $38 \%$ from normotensive values up to $198 \mathrm{mmHg}$ systolic. The blood pressure response was paralleled by a corresponding increase in ANG II levels. In the presence of the human-specific renin inhibitor, RO 425892, the hypertensive response to human renin infusions as well as the rise in plasma ANG II could be completely inhibited. This indicates that (a) the interaction of human renin with human AOGEN is the sole cause of ANG II formation, (b) the transgenic human AOGEN gene product shows functional integrity, and (c) human renin does not interact with rat AOGEN. When rat renin is infused in TGR (hAOGEN), eliciting an equipressor response compared with i.v. human renin, the addition of RO 425892 does not lower the blood pressure. Thus, in this case, the rise in blood pressure is due to the interaction of rat renin with rat AOGEN.

The TGR (hREN) and TGR (hAOGEN) are valid models for the investigation of the regulation of human RAS genes in vivo. Furthermore, since these transgenic rats are accessible to hemodynamic or endocrinological investigations, human-specific drugs may be tested without the limitations of a primate model.

\section{Conclusions}

The role of the RAS in hypertension and other cardiovascular diseases is becoming increasingly important. One of the most relevant aspects in this respect was the verification of local synthesis of its components in several organs using molecular biological techniques, which suggested the possibility of paracrine-autocrine functions of local RAS besides the classical hormonal RAS acting on an endocrine level. In vitro studies on isolated tissues such as vascular smooth muscle cells or cardiomycytes demonstrated conversion of ANG I to ANG II and activation of intracellular signal transduction pathways confirming the hypothesis of paracrine functions. The local interaction with other neurosecretory systems, in particular the sympathetic nervous system represents an important aspect of the function of tissue RAS. ANG II also has potent direct effects on myocardial contractility and may have deleterious effects during ischemia and reperfusion. These findings support the view that structural changes occuring during the chronic state of hypertension such as cardiovascular hypertrophy are possibly mediated by local RAS. The possible physiological significance of locally generated ANG II was suggested indirectly by the antihypertensive and cardioprotective effect of CEI, which strongly supports the view that the RAS is substantially involved in the pathogenesis of cardiovascular disease.

The regulation of the genes of the RAS has been shown to be altered in several models of primary hypertension. However, the underlying mechanisms of the pathogenesis remained to be elucidated. The established transgenic animal model systems will be of great value to investigate the cardiovascular effects of the RAS in further detail. To achieve this goal, new model systems will be necessary, such as 
transgenic rats with other genes of the RAS or animals, which overproduce genes of the RAS only in specific tissues. In addition, it will be useful to "switch off" the activity of these genes in animals via antisense inhibition (266) or homologous recombination in embryonic stem cells (267) in order to create new animal models which lack RAS activity partly or totally.

Despite this increasing importance, the RAS is only one of many systems involved in cardiovascular regulation and hypertension. The genetic studies are far from being complete, so that we may expect new interesting candidate genes, which point to other systems also involved in these processes. To evaluate their relevance for hypertension, one has to develop model systems, e.g. transgenic animals, for other peptides, such as endothelin, vasopressin or the atrial natriuretic factor (268).

However, one has to be very careful in transferring the results obtained in animals and cell cultures to the human situation since species differences are especially marked in cardiovascular regulation. If this is kept in mind, the described experimental approaches will be valuable tools in the investigation and treatment of primary hypertension.

\section{References}

1. Wright JW, Roberts KA, Harding JW: Drinking to intracerebroventricularly infused angiotensin II, III, and IV in the SHR. Peptides 1988; 9: 979-984.

2. Yin D-C, Chan JYH, Chan SHH: Interaction between angiotensin III and $\alpha_{2}$-adrenoceptors of the medulla oblongata involved in cardiovascular regulation in the rat. Regul Pept 1990; 29: 59-72.

3. Ferrario CM, Brosnihan KB, Diz DI, et al: Angiotensin- (1-7): A new hormone of the angiotensin system. Hypertension 1991; 18 [suppl III]: III126-III-133.

4. Urata H, Kinoshita A, Misono KS, Bumpus FM, Husain A: Identification of a highly specific chymase as the major angiotensin II-forming enzyme in the human heart. J Biol Chem 1990; 265: 22348-22357.

5. Hilbert $\mathrm{P}$, Lindpaintner $\mathrm{K}$, Beckmann JS, et al: Chromosomal mapping of two genetic loci associated with blood-pressure regulation in hereditary hypertensive rats. Nature 1991; 353: 521-529.

6. Jacob HJ, Lindpaintner K, Lincoln SE, et al: Genetic mapping of a gene causing hypertension in the stroke-prone spontaneously hypertensive rat. Cell 1991; 67: 213-224.

7. Jeunemaitre X, Soubrier F, Kotelevtsev YV, et al: Molecular basis of human hypertension: role of angiotensinogen. Cell 1992; 71: 169-180.

8. Cambien F, Poirier O, Lecerf L, et al: Deletion polymorphism in the gene for angiotensin-converting enzyme is a potent risk factor for myocardial infarction. Nature 1992; 359: 641-644.

9. Dzau VJ: Vascular renin-angiotensin: a possible autocrine or paracrine system in control of vascular function. $J$ Cardiovasc Pharmacol 1984; 6: S377-S382.

10. Paul M, Bachmann J, Ganten D: The tissue reninangiotensin systems in cardiovasculr disease. Trends Cardiovasc Med 1992; 2: 94-99.

11. Hackenthal E, Paul M, Ganten D, Taugner R: Morphology, physiology, and molecular biology of renin secretion. Physiol Rev 1990; 70: 1067-1116.
12. Unger Th, Ganten D, Lang RE: Converting enzyme inhibitors: antihypertensive drugs with unexpected mechanisms. Trends Pharmacol Sci 1983; 4: 514-519.

13. Bruneval P, Fournier JG, Soubrier F, et al: Detection and localization of renin messenger RNA in human pathologic tissues using in situ hybridization. Am J Pathol 1988; 131: 320-330.

14. Paul M, Wagner J, Dzau VJ: Gene expression of the components of the renin-angiotensin system in human tissues: quantitative analysis by the polymerase chain reaction. J Clin Invest 1993; 91: 2058-2064.

15. Mullins JJ, Peters J, Ganten D: Fulminant hypertension in transgenic rats harbouring the mouse Ren-2 gene. Nature 1990; 344: 541-544.

16. Ganten D: Role of animal models in hypertension research. Hypertension 1987; 9 (Suppl I): I-2-I-4.

17. Ganten D, Wagner J, Zeh K, et al: Species specificity of renin kinetics in transgenic rats harboring the human renin and angiotensinogen genes. Proc Natl Acad Sci USA 1992; 89: 7806-7810.

18. Ganten D, Minnich JL, Granger $\mathrm{P}$, et al: Angiotensin-forming enzyme in brain tissue. Science 1971; 173: 64-65.

19. Ganten D, Hermann K, Bayer C, Unger Th, Lange RE: Angiotensin synthesis in the brain and increased turnover in hypertensive rats. Science 1983; 221: 869-871.

20. Samani NJ, Morgan K, Brammar WJ, Swales JD: Detection of renin messenger RNA in rat tissues: increased sensitivity using an RNAse protection technique. J Hypertens 1987; 5 (suppl 2): S19-S21.

21. Samani NJ, Swales JD, Brammar WJ: Expression of the renin gene in extra-renal tissues of the rat. Biochem J 1988; 253: 907-910.

22. Dzau VJ, Ellison KE, Brody T, Ingelfinger $\mathbf{J}$, Pratt RE: A comparative study of the distributions of renin and angiotensinogen messenger ribonucleic acids in rat and mouse tissues. Endocrinology 1987; 120: 2334-2338.

23. Paul M, Schunkert H, Allen P, Dzau VJ: Widespread distribution of angiotensin converting enzyme mRNA in human tissues. J Hypertens 1990; 8 (suppl 3): S36. (Abstract)

24. Sasaki K, Yamano Y, Bardhan S, et al: Cloning and expression of a complementary DNA encoding a bovine adrenal angiotensin II type-1 receptor. Nature 1991; 351: 230-232.

25. Murphy TJ, Alexander RW, Griendling KK, Runge MS, Bernstein KE: Isolation of a cDNA encoding the vascular type-1 angiotensin II receptor. Nature 1991; 351: 233-236.

26. Mukoyama M, Nakajima M, Horiuchi M, Sasamura H, Pratt RE, Dzau VJ: Expression cloning of type angiotensin II receptor reveals a unique class of seven-transmembrane receptors. J Biol Chem 1993; 268: 24539-24542.

27. Kambayashi $\mathrm{Y}$, Bardhan $\mathrm{S}$, Takahashi $\mathrm{K}$, Inui $\mathrm{H}$, Hamakubo $\mathrm{T}$, Inagami $\mathrm{T}$ : Molecular cloning of a novel angiotensin II receptor isoform involved in phosphotyrosine phosphatase inhibition. $\mathrm{J} \mathrm{Biol} \mathrm{Chem}$ 1993; 268: $24543-24546$.

28. Unger Th, Ganten D, Lang RE: Tissue converting enzyme and cardiovascular actions of converting enzyme inhibitors. J Cardiovasc Pharmacol 1986; 8 (suppl 10): S75-S81.

29. Laragh $\mathbf{J H}$ : Extrarenal tissue prorenin systems do exist: are intrinsic vascular and cardiac tissue renins fact or fancy. Am J Hypertens 1989; 2: 262-265.

30. Cook WF: The detection of renin in juxtaglomerular cells. J Physiol 1968; 194: 73P-74P.

31. Taugner $\mathrm{R}$, Hackenthal $\mathrm{E}$, Inagami $\mathrm{T}$, Nobiling R, 
Poulsen K: Vascular and tubular renin in the kidneys of mice. Histochemistry 1982; 75: 473-484.

32. Taugner R, Hackenthal E, Helmchen U, et al: The intrarenal renin-angiotensin-system: an immunocytochemical study on the localization of renin, angiotensinogen, converting enzyme and the angiotensins in the kidney of mouse and rat. Klin Wochenschr 1982; 60: 1218-1222.

33. Deschepper CF, Mellon SH, Cumin F, Baxter JD, Ganong WF: Analysis by immunocytochemistry and in situ hybridization of renin and its mRNA in kidney, testis, adrenal, and pituitary of the rat. Proc Natl Acad Sci USA 1986; 83: 7552-7556.

34. Ingelfinger JR, Zuo WM, Fon EA, Ellison KE, Dzau VJ: In situ hybridization evidence for angiotensinogen messenger RNA in the rat proximal tubule: an hypothesis for the intrarenal renin angiotensin system. J Clin Invest 1990; 85: 417-423.

35. Gomez RA, Chevalier RL, Sturgill BC, Johns DW, Peach MJ, Carey RM: Maturation of the intrarenal renin distribution in Wistar-Kyoto (WKY) rats. $J$ Hypertens 1986; 4 (Suppl 5): S31-S33.

36. Page WV, Perlman S, Smith FG, Segar JL, Robillard JE: Renal nerves modulate kidney renin gene expression during the transition from fetal to newborn life. Am J Physiol 1992; 262: R459-R463.

37. Fernandez LA, Twickler J, Mead A: Neovascularization produced by angiotensin II. J Lab Clin Med 1985; 105: 141-145.

38. Gomez RA, Lynch KR, Chevalier RL, et al: Renin and angiotensinogen gene expression and intrarenal renin distribution during ACE inhibition. $A m J$ Physiol 1988; 254: 900-906.

39. Geary KM, Hunt MK, Peach MJ, Gomez RA, Carey RM: Effects of angiotensin converting enzyme inhibition, sodium depletion, calcium, isoproterenol, and angiotensin II on renin secretion by individual renocortical cells. Endocrinology 1992; 131: 1588-1594.

40. Everett AD, Carey RM, Chevalier RL, Peach MJ, Gomez RA: Renin release and gene expression in intact rat kidney microvessels and single cells. J Clin Invest 1990; 86: 169-175.

41. Ludwig G, Ganten D, Murakami K, Fasching U, Hackenthal E: Relationship between renin mRNA and renin secretion in adrenalectomized, salt-depleted, or converting enzyme inhibitor-treated rats. Mol Cell Endocrinol 1987; 50: 223-229.

42. Gomez RA, Chevalier RL, Everett AD, et al: Recruitment of renin gene-expressing cells in adult rat kidneys. Am J Physiol 1990; 259: F660-F665.

43. Naftilan AJ, Oparil S: Inhibition of renin release from rat kidney slices by the angiotensins. Am $J$ Physiol 1978; 235: F62-F68.

44. Keuneke C, Yacullo R, Metzger R, Hellmann W, Peters J, Ganten D: The role of tissue reninangiotensin systems in hypertension and effects of chronic converting-enzyme inhibition. Eur Heart $J$ 1990; 11 (Suppl D): 11-16.

45. Kokubu T, Kitami Y, Muneta S, Murakami E, Hiwada K: Effects of renin inhibitors on the expression of kidney renin gene and tissue renin-like activity. $J$ Hypertens 1989; 7 (Suppl 2): S29-S32.

46. Ingelfinger JR, Pratt RE, Ellison $K$, Dzau VJ: Sodium regulation of angiotensinogen mRNA expression in rat kidney cortex and medulla. J Clin Invest 1986; 78: 1311-1315.

47. Iwao H, Fukui K, Kim S, et al: Sodium balance effects on renin, angiotensinogen, and atrial natriuretic polypeptide mRNA levels. Am J Physiol 1988; 255: $129-136$

48. Dzau VJ, Carlton JE, Brody T: Sequential changes in renin secretion-synthesis coupling in response to acute $\beta$-adrenergic stimulation. Clin Res 1987; 35: 604A.

49. Rosenberg ME, Chmielewski D, Hostetter TH: Effect of dietary protein on rat renin and angiotensinogen gene expression. J Clin Invest 1990; 85: 1144-1149.

50. Correa-Rotter R, Hostetter TH, Rosenberg ME: Effect of dietary protein on renin and angiotensinogen gene expression after renal ablation. Am J Physiol 1992; 262: F631-F638.

51. El-Dahr SS, Gomez RA, Gray MS, Peach MJ, Carey RM, Chevalier RL: In situ localization of renin and its mRNA in neonatal ureteral obstruction. $A m J$ Physiol 1990; 258: F854-F862.

52. El-Dahr SS, Gomez RA, Gray MS, Peach MJ, Carey RM, Chevalier RL: Renal nerves modulate renin gene expression in the developing rat kidney with ureteral obstruction. J Clin Invest 1991; 87: 800-810.

53. Nakamura N, Soubrier F, Menard J, Panthier JJ, Rougeon F, Corvol P: Nonproportional changes in plasma renin concentration, renal renin content, and rat renin messenger RNA. Hypertension 1985; 7: 855-859.

54. Paller MS, Hostetter TH: Dietary protein increases plasma renin and pressor reactivity to angiotensin II. Am J Physiol 1986; 251: F34-F39.

55. Wagner J, Stein G, Mann J, Ritz E: Influence of dietary factors on the renal renin-angiotensin-system. Klin Wochenschr 1992; 69 (Suppl. XXIX): 35-38.

56. von Lutterotti N, Gulmi F, Marion D, Vaughan ED, Laragh JH, Sealey JE: Increased plasma prorenin but not renin after bilateral ureteral ligation in dogs. Kidney Int 1991; 39: 901-908.

57. Morris BJ, Johnston CI: Renin substrate in granules from rat kidney cortex. Biochem $J$ 1976; 154: 625-637.

58. Richoux JP, Cordonnier JL, Bouhnik J, et al: Immunocytochemical localization of angiotensinogen in rat liver and kidney. Cell Tissue Res 1983; 233: 439-451.

59. Goldstein DJ, Diaz A, Finkielman S, Nahmod VE, Fischer-Ferraro C: Regulation of the in vitro synthesis of angiotensin I. Proc Soc Exp Biol Med 1973; 142: 793-795.

60. Campbell DJ, Habener JF: Angiotensinogen gene is expressed and differentially regulated in multiple tissues of the rat. J Clin Invest 1986; 78: 31-39.

61. Kalinyak JE, Perlman AJ: Tissue-specific regulation of angiotensinogen mRNA accumulation by dexamethasone. J Biol Chem 1987; 262: 460-464.

62. Ohkubo H, Nakayama K, Tanaka T, Nakanishi S: Tissue distribution of rat angiotensinogen mRNA and structural analysis of its heterogeneity. $\mathrm{J} \mathrm{Biol} \mathrm{Chem}$ 1986; 261: 319-323.

63. Fried TA, Simpson EA: Intrarenal localization of angiotensinogen mRNA by RNA-DNA dot-blot hybridization. Am J Physiol 1986; 250: F374-F377.

64. Pratt RE, Zou WM, Naftilan AJ, Ingelfinger JR, Dzau VJ: Altered sodium regulation of renal angiotensinogen mRNA in the spontaneously hypertensive rat. Am J Physiol 1989; 256: 469-474.

65. Ellison KE, Ingelfinger JR, Pivor $\mathrm{M}$, Dzau VJ: Androgen regulation of rat renal angiotensinogen messenger RNA expression. J Clin Invest 1989; 83: 1941-1945.

66. Yanagawa N, Capparelli AW, Jo OD, Friedal A, Barrett JD, Eggena P: Production of angiotensinogen and renin-like activity by rabbit proximal tubular cells in culture. Kidney Int 1991; 39: 938-941.

67. Oshima G, Gecse A, Erdös EG: Angiotensin I-con- 
verting enzyme of the kidney cortex. Biochem Biophys Acta 1974; 350: 26-37.

68. Ward PE, Erdös EG, Gedney CD, Dowben RM, Reynolds RC: Isolation of membrane-bound renal enzymes that metabolize kinins and angiotensins. Biochem J 1976; 157: 643-650.

69. Roth M, Weitzman AF, Piquilloud Y: Converting enzyme content of different tissues of the rat. Experientia 1969; 25: 1247.

70. Caldwell PRB, Seegal BC, Hsu KC, Das M, Soffer RL: Angiotensin-converting enzyme: vascular endothelial localization. Science 1976; 191: 1050-1051.

71. Erdös EG, Skidgel RA: The unusual substrate specificity and the distribution of human angiotensin I converting enzyme. Hypertension 1986; 8 (suppl 1): I34-I-37.

72. Defendini R, Zimmerman EA, Weare JA, AlhencGelas F, Erdös EG: Angiotensin-converting enzyme in epithelial and neuroepithelial cells. Neuroendocrinology 1983; 37: 32-40.

73. Rix E, Ganten D, Schüll B, Unger Th, Taugner R: Converting-enzyme in the choroid plexus, brain, and kidney: immunocytochemical and biochemical studies in rats. Neurosci Lett 1981; 22: 125-130.

74. Taugner R, Ganten D: The localization of converting enzyme in kidney vessels of the rat. Histochemistry 1982; 75: 191-201.

75. Bruneval $\mathrm{P}$, Hinglais $\mathrm{N}$, Alhenc-Gelas $\mathrm{F}$, et al: Angiotensin I converting enzyme in human intestine and kidney. Histochemistry 1986; 85: 73-80.

76. Schulz WW, Hagler HK, Buja LM, Erdös EG: Ultrastructural localization of angiotensin I-converting enzyme (EC 3.4.15.1) and neutral metalloendopeptidase (EC 3.4.24.11) in the proximal tubule of the human kidney. Lab Invest 1988; 59: 789-797.

77. Alhenc-Gelas F, Baussant T, Hubert C, Soubrier F, Corvol P: The angiotensin converting enzyme in the kidney. J Hypertens 1989; 7 (suppl 7): S9-S14.

78. Chang RSL, Lotti VJ: Angiotensin receptor subtypes in rat, rabbit and monkey tissue: relative distribution and species dependency. Life Sci 1991; 49: 1485-1490.

79. Mendelsohn FAO, Aguilera G, Saavedra JM, Quirion $\mathrm{R}$, Catt $\mathrm{KJ}$ : Characteristics and regulation of angiotensin II receptors in pituitary, circumventricular organs and kidney. Clin Exp Hypertens [A] 1983; 5: $108 \mathrm{i}-1097$.

80. Douglas JG: Angiotensin receptor subtypes of the kidney cortex. Am J Physiol 1987; 253: F1-F7.

81. Sraer JD, Sraer J, Ardaillou R, Mimoune O: Evidence for renal glomerular receptors for angiotensin II. Kidney Int 1974; 6: 241-246.

82. Brown GP, Douglas JG, Krontris-Litowitz J: Properties of angiotensin II receptors of isolated rat glomeruli factors influencing binding affinity and comparative binding of angiotensin analogs. Endocrinology 1980; 106: 1923-1929.

83. Brown CA, Zusman RM, Haber E: Identification of an angiotensin receptor in rabbit renomedullary interstitial cells in tissue culture. Circ Res 1980; 46: 802-807.

84. Brown GP, Douglas JG: Angiotensin II binding sites on isolated rat renal brush border membranes. Endocrinology 1982; 111: 1830-1836.

85. Mendelsohn FAO: Localization and properties of angiotensin receptors. J Hypertens 1985; 3: 307-316.

86. Mendelsohn FAO, Dunbar M, Allen A, et al: Angiotensin II receptors in the kidney. Fed Proc 1986; 45: 1420-1425.

87. Zhuo J, Alcorn D, Allen AM, Mendelsohn FAO: High resolution localization of angiotensin II recep- tors in rat renal medulla. Kidney Int 1992; 42: 1372-1380.

88. Levens NR, Peach MJ, Carey RM: Role of the intrarenal renin-angiotensin system in the control of renal function. Circ Res 1981; 48: 157-167.

89. Mundel P, Bachmann S, Bader M, et al: Expression of nitric oxide synthase in kidney macula densa cells. Kidney Int 1992; 42: 1017-1019.

90. Skott O, Briggs JP: Direct demonstration of macula densa-mediated renin secretion. Science 1987; 237: 1618-1620.

91. Freeman RH, Davis JO, Gotshall RW, Johnson JA, Spielman WS: The signal perceived by the macula densa during changes in renin release. Circ Res 1974; 35: $307-315$.

92. Corsini WA, Hook JB, Bailie MD: Control of renin secretion in the dog. Circ Res 1975; 37: 464-470.

93. Kotchen TA, Galla JH, Luke RG: Contribution of chloride to the inhibition of plasma renin by sodium chloride in the rat. Kidney Int 1978; 13: 201-207.

94. Inagami $T$, Kawamura $M$, Naruse $K$, Okamura $T$ : Localization of components of the renin-angiotensin system within the kidney. Fed Proc 1986; 45: 1414-1419.

95. Leyssac PP: Changes in single nephron rrenin release are mediated by tubular fluid flow rate. Kidney Int 1986; 30: 332-339.

96. Mendelsohn FAO: Evidence for the local occurence of angiotensin II in rat kidney and its modulation by dietary sodium intake and converting enzyme blockade. Clin Sci 1979; 57: 173-179.

97. Seikaly MG, Arant BS, Seney FDJr: Endogenous angiotensin concentrations in specific renal fluid compartments of the rat. J Clin Invest 1990; 86: 1352-1357.

98. Harris PJ, Young JA: Dose-dependent stimulation and inhibition of proximal tubular sodium reabsorption by angiotensin II in the rat kidney. Pfluegers Arch 1977; 367: 295-297.

99. Harris PJ, Navar LG: Tubular transport responses to angiotensin. Am J Physiol 1985; 248: F621-F630.

100. Schuster VL, Kokko JP, Jacobson HR: Angiotensin II directly stimulates sodium transport in rabbit proximal convoluted tubules. J Clin Invest 1984; 73: 507-515.

101. Schuster VL: Effects of angiotensin on proximal tubular reabsorption. Fed Proc 1986; 45: 1444-1447.

102. Hall JE: Regulation of glomerular filtration rate and sodium excretion by angiotensin II. Fed Proc 1986; 45: 1431-1437.

103. Cogan MG: Angiotensin II: a powerful controller of sodium transport in the early proximal tubule. Hypertension 1990; 15: 451-458.

104. Liu F-Y, Cogan MG: Angiotensin II: a potent regulator of acidification in the rat early proximal convoluted tubule. J Clin Invest 1987; 80: 272-275.

105. Liu F-Y, Cogan MG: Angiotensin II stimulation of hydrogen ion secretion in the rat early proximal tubule. J Clin Invest 1988; 82: 601-607.

106. Chobanian MC, Julin CM: Angiotensin II stimulates ammoniagenesis in canine renal proximal tubule segment. Am J Physiol 1991; 260: F19-F26.

107. Nagami GT: Effect of angiotensin II on ammonia production and secretion by mouse proximal tubules perfused in vitro. J Clin Invest 1992; 89: 925-931.

108. Myers BD, Deen WM, Brenner BM: Effects of norepinephrine and angiotensin II on the determinants of glomerular ultrafiltration and proximal tubule fluid reabsorption in the rat. Circ Res 1975; 37: 101-110.

109. Blantz RC, Konnen KS, Tucker BJ: Angiotensin II effects upon the glomerular microcirculation and 
ultrafiltration coefficient of the rat. $J$ Clin Invest 1976; 57: 419-434.

110. Ichikawa I, Miele JF, Brenner BM: Reversal of renal cortical actions of angiotensin II by verapamil and manganese. Kidney Int 1979; 16: 137-147.

111. Schor N, Ichikawa I, Brenner BM: Mechanism of action of various hormones and vasoactive substances on glomerular ultrafiltration in the rat. Kidney Int 1981; 20: 442-451.

112. Edwards RM: Segmental effects of norepinephrine and angiotensin II on isolated renal microvessels. $\mathrm{Am}$ J Physiol 1983; 244: F526-F534.

113. Ichikawa I, Brenner BM: Glomerular actions of angiotensin II. Am J Med 1984; 76 (5B): 43-49.

114. Chou S-Y, Faubert PF, Porush JG: Contribution of angiotensin to the control of medullary hemodynamics. Fed Proc 1986; 45: 1438-1443.

115. Biron P, Meyer P, Panisset J-C: Removal of angiotensins from the systemic circulation. Can $J$ Physiol Pharmacol 1968; 46: 175-178.

116. Leary WP, Ledingham JG: Removal of angiotensin by isolated perfused organs of the rat. Nature 1969; 222: 959-960.

117. Rosivall L, Narkates AJ, Oparil S, Navar LG: De nove intrarenal formation of angiotensin II during control and enhanced renin secretion. Am J Physiol 1987; 252: F1118-F1123.

118. Norman J, Badie-Dezfoooly B, Nord EP, et al: EGFinduced mitogenesis in proximal tubular cells: potentiation by angiotensin II. Am J Physiol 1987; 253: F299-F309.

119. Wolf G, Neilson EG: Angiotensin II induces cellular hypertrophy in cultured murine proximal tubular cells. Am J Physiol 1990; 259: F768-F777.

120. Norman JT: The role of angiotensin II in renal growth. Renal Physiol Biochem 1991; 14: 175-185.

121. Johnson RJ, Alpers CE, Yoshimura A, et al: Renal injury from angiotensin II-mediated hypertension. Hypertension 1992; 19: 464-474.

122. von Lutterotti N, Camargo MJF, Campbell WGJr, et al: Angiotensin II receptor antagonist delays renal damage and stroke in salt-loaded Dahl salt-sensitive rats. J Hypertens 1992; 10: 949-957.

123. Kakinuma Y, Kawamura T, Bills T, Yoshioka T, Ichikawa I, Fogo A: Blood pressure-independent effect of angiotensin inhibition on vascular lesions of chronic renal failure. Kidney Int 1992; 42: 46-55.

124. Apperloo AJ, de Zeeuw D, Sluiter HE, de Jong PE: Differential effects of enalapril and atenolol on proteinuria and renal haemodynamics in non-diabetic renal disease. Br Med J 1991; 303: 821-824.

125. Björck S, Mulec H, Johnsen SA, Nordén G, Aurell M: Renal protective effect of enalapril in diabetic nephropathy. $\mathrm{Br}$ Med J 1992; 304: 339-343.

126. Anderson S: Renal effects of converting enzyme inhibitors in hypertension and diabetes. J Cardiovasc Pharmacol 1990; 15 (suppl 3): S-11-S-15.

127. Brown MA, Whitworth JA: Hypertension in human renal disease. J Hypertens 1992; 10: 701-712.

128. Hutchinson FN, Schambelan M, Kaysen GA: Modulation of albuminuria by dietary protein and converting enzyme inhibition. Am J Physiol 1987; 253: F719-F725.

129. Ichikawa I, Pfeffer JM, Pfeffer MA, Hostetter TH, Brenner BM: Role of angiotensin II in the altered renal function of congestive heart failure. Circ Res 1984; 55: 669-675.

130. Schunkert H, Hirsch AT, Mankodi S, Talsness C, Dzau VJ, Ingelfinger JR: Renal angiotensinogen gene expression in experimental heart failure: effect of angiotensin converting enzyme inhibition. Clin Res
1989; 37: 584A (abstract).

131. Cohen M, Kurtz KD: Angiotensin converting enzyme inhibition in tissues from spontaneously hypertensive rats after treatment with captopril and MK421.J Pharmacol Exp Ther 1982; 220: 63-69.

132. Unger Th, Ganten D, Lang RE, Schölkens BA: Persistent tissue converting enzyme inhibition following chronic treatment with HOE498 in spontaneously hypertensive rats. J Cardiovasc Pharmacol 1985; 7: $36-41$.

133. Samani NJ, Godfrey NP, Major JS, Brammar WJ, Swales JD: Kidney renin mRNA levels in the early and chronic phases of two-kidney, one clip hypertension in the rat. J Hypertens 1989; 7: 105-112.

134. Moffett RB, McGowan RA, Gross KW: Modulation of kidney renin messenger RNA levels during experimentally induced hypertension. Hypertension 1986; 8: 874-882.

135. Guan S, Fox J, Mitchell KD, Navar LG: Angiotensin and angiotensin converting enzyme tissue levels in two-kidney, one clip hypertensive rats. Hypertension 1992; 20: 763-767.

136. Burnier M, Waeber B, Nussberger J, Brunner HR: Effect of angiotensin converting enzyme inhibition in renovascular hypertension. J Hypertens 1989; 7 (suppl 7): S27-S31.

137. Samani NJ, Swales JD, Brammar WJ: A widespread abnormality of renin gene expression in the spontaneously hypertensive rat: modulation in some tissues with the development of hypertension. Clin Sci 1989; 77: 629-636.

138. Kitami Y, Hiwada K, Kokubu T: Kidney renin gene expression in spontaneously hypertensive rats. $J$ Hypertens 1989; 7: 727-731.

139. Hellmann W, Suzuki F, Ohkubo H, Nakanishi S, Ludwig G, Ganten D: Angiotensinogen gene expression in extrahepatic rat tissues: application of a solution hybridization assay. Naunyn-Schmiedeberg's Arch Pharmacol 1988; 338: 327-331.

140. Lindpaintner K, Jin M, Niedermeier N, Wilhelm MJ, Ganten D: Cardia cangiotensinogen and its local activation in the isolated perfused beating heart. Circ Res 1990; 67: 564-573.

141. Sawa H, Tokuchi F, Mochizuki N, et al: Expression of the angiotensinogen gene and localization of its protein in the human heart. Circulation 1992; 86: $138-146$.

142. Dzau VJ, Re RN: Evidence for the existence of renin in the heart. Circulation 1987; 75 (suppl I): I-134-I-136

143. Dzau VJ, Brody T, Ellison KE, Pratt RE, Ingelfinger JR: Tissue-specific regulation of renin expression in the mouse. Hypertension 1987; 9 (Suppl III): III-36-III-41.

144. Paul M, Wagner D, Metzger R, et al: Quantification of renin mRNA in various mouse tissues by a novel solution hybridization assay. J Hypertens 1988; 6: 247-252.

145. Saito K, Gutkind JS, Saavedra JM: Angiotensin II binding sites in the conduction system of rat hearts. Am J Physiol 1987; 253: H1618-H1622.

146. Rogers TB, Gaa ST, Allen IS: Identification and characterization of functional angiotensin II receptors on cultured heart myocytes. J Pharmacol Exp Ther 1986; 236: 438-444.

147. Urata H, Healy B, Stewart RW, Bumpus FM, Husain A: Angiotensin II receptors in normal and failing human hearts. J Clin Endocrinol Metab 1989; 69: 54-66.

148. Rogg H, Schmid A, de Gasparo M: Identification and characterization of angiotensin II receptor sub- 
types in rabbit ventricular myocardium. Biochem Biophys Res Commun 1990; 173: 416-422.

149. Dzau VJ: Implications of local angiotensin production in cardiovascular physiology and pharmacology. Am J Cardiol 1987; 59: 59A-65A.

150. Lindpaintner K, Jin M, Wilhelm MJ, et al: Intracardiac generation of angiotensin and its physiologic role. Circulation 1988; 77 (suppl 1): I-18-I-23.

151. Lindpaintner K, Ganten D: The cardiac reninangiotensin system-an appraisal of present experimental and clinical evidence. Circ Res 1991; 68: 905-921.

152. Koch-Weser J: Myocardial actions of angiotensin. Circ Res 1964; 14: 337-344.

153. Koch-Weser J: Nature of the inotropic action of angiotensin on ventricular myocardium. Circ Res 1965; 16: 230-237.

154. Kobayashi M, Furukawa Y, Chiba S: Positive chronotropic and inotropic effects of angiotensin II in the dog heart. Eur J Pharmacol 1978; 50: 17-25.

155. Dempsey PJ, McCallum ZT, Kent KM, Cooper T: Direct myocardial effects of angiotensin II. Am J Physiol 1971; 220: 477-481.

156. Kent KM, Goodfriend TL, McCallum ZT, Dempsey PJ, Cooper T: Inotropic agents in hypoxic cat myocardium. Circ Res 1972; 30: 196-204.

157. Dösemeci A, Dhallan RS, Cohen NM, Lederer WJ, Rogers TB: Phorbol ester increases calcium current and simulates the effects of angiotensin II on cultured neonatal rat heart myocytes. Cirt Res 1988; 62: 347-357.

158. Allen IS, Cohen NM, Dhallen RS, Gaa ST, Lederer WJ, Rogers TB: Angiotensin II increases spontaneous contractile frequency and stimulates calcium current in cultured neonatal rat heart myocytes: insights into the underlying biochemical mechanisms. Circ Res 1988; 62: 524-534.

159. Linz W, Schoelkens BA, Yi-Fan Han: Beneficial effects of the converting enzyme inhibitor ramipril in ischemia hearts. J Hypertens 1986; 8 (suppl 10): S91-S99.

160. Martorana PA, Kettenbach B, Breipohl G, Linz W, Schölkens BA: Reduction of infarct size by local angiotensin-converting enzyme inhibition is abolished by a bradykinin antagonist. Eur J Pharmacol 1990; 182: 395-396.

161. Bonnardeaux JL, Regoli D: Action of angiotensin and analogues on the heart. Can J Physiol Pharmacol 1974; 52: 50-60

162. Sen S, Tarazi RC, Bumpus FM: Effect of converting enzyme inhibitor on cardiac therapy. Cardiovasc Res 1977; 11: 427.

163. Sen S, Tarazi RC, Bumpus FM: Effect of converting enzyme inhibitor (SQ14225) on myocardial hypertrophy in spontaneously hypertensive rats. Hypertension 1980; 2: 169-176.

164. Kaplan NM: New perspectives in the treatment of hypertension withy arterial disease. $J$ Cardiovasc Pharmacol 1985; 7: S131-S134.

165. Nakashima Y, Fouad FM, Tarazi RC: Regression of left ventricular hypertrophy from systemic hypertension by enalapril. Am J Cardiol 1984; 53: 1044-1049.

166. Baker KM, Chernin MI, Wixson SK, Aceto JF: Renin-angiotensin system involvement in pressureoverload cardiac hypertrophy in rats. Am $J$ Physiol 1990; 259: H324-H332.

167. Niedermaier N, Drexler H, Kaling M, Ganten D: Left ventricular hypertrophy and myocardial infarction increase left ventricular angiotensinogen gene expression. J Hypertens 1991; 9 (suppl 6): S469. (Abstract)
168. Schunkert H, Dzau VJ, Tang SS, Hirsch AT, Apstein $\mathrm{CS}$, Lorell $\mathrm{BH}$ : Increased rat cardiac angiotensin converting enzyme activity and mRNA expression in pressure overload left ventricular hypertrophy. $J$ Clin Invest 1990; 86: 1913-1920.

169. Kromer EP, Riegger GAJ: Effects of longterm angiotensin converting enzym inhibition on myocardial hypertrophy in experimental aortic stenosis in the rat. Am J Cardiol 1988; 62: 161-163.

170. Linz W, Schölkens BA, Ganten D: Converting enzyme inhibition specifically prevents the development and induces regression of cardiac hypertrophy in rats. Clin Exp Hypertens [A] 1989; 11: 1325-1350.

171. Pahor M, Bernabei R, Sgadari A, et al: Enalapril prevents cardiac fibrosis and arrhythmias in hypertensive rats. Hypertension 1991; 18: 148-157.

172. Brilla CG, Janicki JS, Weber KT: Cardioprotective effects of lisinopril in rats with genetic hypertension and left vetricular hypertrophy. Circulation 1991; 83: $1771-1779$

173. Nagano M, Higaki J, Mikami H, et al: Converting enzyme inhibitors regressed cardiac hypertrophy and reduced tissue angiotensin II in spontaneously hypertensive rats. $J$ Hypertens 1991; 9: 595-599.

174. Nagano M, Higaki J, Nakamura F, et al: Role of cardiac angiotensin II in isoproterenol-induced left ventricular hypertrophy. Hypertension 1992; 19: 708-712.

175. Drexler H, Hänze J, Finckh M, Lu W, Just H, Lang RE: Atrial natriuretic peptide in a rat model of cardiac failure. Circulation 1989; 79: 620-633.

176. Finckh M, Hellmann W, Ganten D, et al: Enhanced cardiac angiotensinogen gene expression and angiotensin converting enzyme activity in tachypacing-induced heart failure in rats. Basic Res Cardiol 1991; 86: 303-316.

177. Hirsch AT, Talsness CE, Schunkert H, Paul M, Dzau VJ: Tissue-specific activation of cardiac angiotensin converting enzyme in experimental heart failure. Circ Res 1991; 69: 475-482.

178. Ertl G, Kloner RA, Alexander RW, Braunwald E: Limitation of experimental infarct size by an angiotensin converting enzyme inhibitor. Circulation 1982; 65: 40-48.

179. Cleland JGF, Dargie HJ, Hodsman GP, et al: Captopril in heart failure: a double blind controlled trial. Br Heart J 1984; 52: 529-535.

180. Van Gilst WH, De Graeff PA, Kingma JH, Wesseling $\mathrm{H}$, DeLanges CDJ: Captopril reduces purine loss and reperfusion arrhythmias in the rat heart after coronary artery occlusion. Eur J Pharmacol 1984; 100: $113-117$.

181. Coker SJ, McGrath MT: Can captopril modify experimentally induced arrhythmias? J Mol Cell Cardiol 1986; 17 (suppl 3): 41.

182. Elfellah MS, Ogilvie RI: Effect of vasodilator drugs on coronary occlusion and reperfusion arrhythmias in anesthetized dogs. J Cardiovasc Pharmacol 1985; 7: 826-832.

183. Van Gilst WH, De Graeff PA, Wesseling H, de Langen CDJ: Reduction of reperfusion arrhythmias in the ischemic isolated rat heart by angiotensin converting enzyme inhibitors: a comparison of captopril, enalapril, and HOE 498. J Cardiovasc Pharmacol 1986; 8: 722-728.

184. Westlin W, Mullane K: Does captopril attenuate reperfusion-induced myocardial dysfunction by scavenging free radicals? Circulation 1988; 77 (suppl I): I-30-I-39.

185. Fletcher PJ, Pfeffer JM, Braunwald E: Left ventricular diastolic pressure-volume relations in rats with healed myocardial infaction. Circ Res 1981; 49: 
618-626.

186. Lamas GA, Pfeffer MA: Increased left ventricular volume following myocardial infarction in man. $A m$ Heart $J$ 1986; 111: 30-35.

187. Capasso JM, Jeanty MW, Palackal T, Olivetti G, Anversa P: Ventricular remodeling induced by acute nonocclusive constriction of coronary artery in rats. Am J Physiol 1989; 257: H1983-H1993.

188. Olivetti G, Capasso JM, Sonnenblick EH, Anversa P: Side-to-side slippage of myocytes participates in ventricular wall remodeling acutely after myocardial infarction in rats. Circ Res 1990; 67: 23-34.

189. Weber KT, Janicki JS: Angiotensin and the remodelling of the myocardium. Br J Clin Pharmacol 1989; 28: $141 \mathrm{~S}-150 \mathrm{~S}$.

190. Sen S, Tarazi RC, Bumpus MF: Cardiac effects of angiotensin antagonists in normotensive rats. Clin Sci Mol Med 1979; 56: 439-443.

191. Pfeffer MA, Lamas GA, Vaughan DE, Parisi AF, Braunwald E: Effect of captopril on progressive ventricular dilatation after anterior myocardial infarction. N Engl J Med 1988; 319: 80-86.

192. Pfeffer MA, Braunwald E: Ventricular remodeling after myocardial infarction. Circulation 1990; 81: 1161-1172.

193. CONSENSUS Trial Study Group: Effects of enalapril on mortality in severe congestive heart failure. Results of the Cooperative North Scandinavian Enalapril Survival Study (CONSENSUS). $N$ Engl $J$ Med 1987; 316: 1429-1435.

194. Sharpe N, Smith H, Murphy J, Greaves S, Hart H, Gamble G: Early prevention of left ventricular dysfunction after myocardial infarction with angiotensinconverting-enzyme inhibition. Lancet 1991; 337: 872-876.

195. Sharpe N, Murphy J, Smith H, Hannan S: Treatment of patients with symptomless left ventricular dysfunction after myocardial infarction. Lancet 1988; I: 255-259.

196. Pfeffer MA, Braunwald E, Moyé LA, et al: Effect of captopril on mortality and morbidity in patients with left ventricular dysfunction after myocardial infarction. N Engl J Med 1992; 327: 669-677.

197. Swedberg K, Held P, Kjekshus J, Rasmussen K, Ryden L, Wedel H: Effects of early administration of enalapril on mortality in patients with acute myocardial infarction. N Engl J Med 1992; 327: 678-684.

198. SOLVD: Effects of enalapril on mortality and the development of heart failure in asymptomatic patients with reduced left ventricular ejection fractions. $N$ Engl J Med 1992; 327: 685-691.

199. Griendling KK, Berk BC, Socorro L, Tsuda T, Delafontaine $\mathrm{P}$, Alexander RW:Secondary signalling mechanisms in angiotensin II-stimulated vascular smooth muscle cells. Clin Exp Pharmacol Physiol 1988; 15: 105-112.

200. Dengler H: Über einen reninartigen Wirkstoff in Arterienextrakten. Arch Exp Path Pharmakol 1956; 227: 481-487.

201. Ganten D, Hayduk K, Brecht HM, Boucher R, Genest $\mathrm{J}$ : Evidence of renin release or production in splanchnic territory. Nature 1970; 226: 551-552.

202. Thurston H, Swales JD, Bing RF, Hurst BC, Marks EF: Vascular renin-like activity and blood pressure maintenance in the rat. Hypertension 1979; 1 : 643-649.

203. Ekker M, Tronik D, Rougeon F: Extra-renal transcription of the renin genes in multiple tissues of mice and rats. Proc Natl Acad Sci USA 1989; 86: 5155-5158.

204. Holycross BJ, Saye J, Harrison JK, Peach MJ:
Polymerase chain reaction analysis of renin in rat aortic smooth muscle. Hypertension 1992; 19: 697-701.

205. Naftilan AJ, Pratt RE, Dzau VJ: Induction of platelet-derived growth factor A-chain and c-myc gene expressions by angiotensin II in cultured rat vascular smooth muscle cells. J Clin Invest 1989; 83: 1419-1424.

206. Naftilan AJ, Pratt RE, Dzau VJ: Localization and differential regulation of angiotensinogen mRNA expression in the vessel wall. Clin Res 1988; 35: 553A.

207. Nakamura Y, Nakamura K, Nakamura K: Difference in response of vascular angiotensin converting enzyme activity to cilazapril in SHR. Clin Exp Hypertens [A] 1987; 9: 351-355.

208. Miyazaki M, Okamura T, Okunishi H, Toda N: Vascular angiotensin converting enzyme in the development of renal hypertension. J Cardiovasc Pharmacol 1986; 8 (suppl 10): S58-S61.

209. Andre P, Schott C, Nehlig H, Stoclet J-C: Aortic smooth muscle cells are able to convert angiotensin I to angiotensin II. Biochem Biophys Res Commun 1990; 173: 1137-1142.

210. Oliver JA, Sciacca RR: Local generation of angiotensin II as a mechanism of regulation of peripheral vascular tone in the rat. J Clin Invest 1984; 74: 1247-1251.

211. Mizuno K, Nakamura M, Higashimori K, Inagami T: Local generation and release of angiotensin II in peripheral vascular tissue. Hypertension 1988; 11: 223-229.

212. Hilgers KF, Kuczera M, Wilhelm MJ, et al: Angiotensin formation in the isolated rat hindlimb. $J$ Hypertens 1989; 7: 789-798.

213. Hilgers KF, Mann JFE, Hilgenfeldt U, Ganten D: Vascular production and regulation of angiotensin. Blood Vess 1991; 28: 201-209.

214. Nakamura $M$, Jackson EK, Inagami $T$ : $\beta$ Adrenoceptor-mediated release of angiotensin II from mesenteric arteries. Am J Physiol 1986; 250: H144-H148.

215. Taddei S, Virdis A, Favilla S, Slavetti A: Adenosine activates a vascular renin-angiotensin system in hypertensive subjects. Hypertension 1992; 19: 672-675.

216. Okamura $\mathrm{T}$, Miyazaki $\mathrm{M}$, Inagami $\mathrm{T}$, Toda $\mathrm{N}$ : Vascular renin-angiotensin system in two-kidney, one clip hypertensive rats. Hypertension 1986; 8: 560-565.

217. Admiraal PJJ, Derkx FHM, Danser AHJ, Pieterman $\mathrm{H}$, Schalekamp MADH: Metabolism and production of angiotensin I in different vascular beds in subjects with hypertension. Hypertension 1990; 15: 44-55.

218. Schelling P, Ganten D, Speck G, Fischer H: Effects of angiotensin II and angiotensin II antagonist saralasin on cell growth and renin in 3T3 and SV3T3 cells. J Cell Physiol 1979; 98: 503-514.

219. Paul M, Ganten D: The molecular basis of cardiovascular hypertrophy: the role of the renin angiotensin system. J Cardiovasc Pharmacol 1992; 19 (suppl 5): S51-S58.

220. Schelling P, Fischer H, Ganten D: Angiotensin and cell growth: a link to cardiovascular hypertrophy? $J$ Hypertens 1991; 9: 3-15.

221. Cambell-Boswell M, Robertson AL: Effects of angiotensin II and vasopressin on human smooth muscle cells in vitro. Exp Mol Pathol 1981; 35: 265-276.

222. Geisterfer AAT, Peach MJ, Owens GK: Angiotensin II induces hypertrophy, not hyperplasia, of cultured rat aortic smooth muscle cells. Circ Res 1988; 62: $749-756$ 
223. Berk BC, Vekstein V, Gordon HM, Tsuda T: Angiotensin II-stimulated protein synthesis in cultured vascular smooth muscle cells. Hypertension 1989; 13:305-314.

224. Schneider MD, Parker TG: Cardiac myocytes as targets for the action of peptide growth factors. Circulation 1991; 81: 1443-1456.

225. Taubman MB, Berk BC, Izumo S, Tsuda T, Alexander RW, Nadal-Ginard B:Angiotensin induces $c$-fos mRNA in aortic smooth muscle: role of $\mathrm{Ca}^{2+}$ mobilization and protein kinase $\mathrm{C}$ activation. $\mathrm{J}$ Biol Chem 1989; 264: 526-530.

226. Naftilan AJ, Pratt RE, Eldridge CS, Lin HL, Dzau VJ: Angiotensin II induces c-fos expression in smooth muscle via transcriptional control. Hypertension 1989; 13: 706-711.

227. Naftilan AJ, Gilliland GK, Eldridge CS, Kraft AS: Induction of the proto-oncogene $c$-jun by angiotensin II. Mol Cell Biol 1990; 10: 5536-5540.

228. Bobik A, Grinpukel S, Little PJ, Grooms A, Jackman G: Angiotensin II and noradrenaline increase PDGF-BB receptors and potentiate PDGF-BB stimulated DNA synthesis in vascular smooth muscle. Biochem Biophys Res Commun 1990; 166: 580-588.

229. Rainer RS, Eldridge CS, Gilliland GS, Naftilan AJ: Antisense oligonucleotide to $c$-fos blocks the angiotensin-II stimulation of protein synthesis in rat aortic smooth muscle cells. Hypertension 1990; 16: 326. (Abstract)

230. Itoh H, Pratt RE, Dzau VJ: Antisense oligonucleotides complementary to PDGF mRNA attenuate angiotensin-II induced vascular hypertrophy. Hypertension 1990; 16: 325. (Abstract)

231. Powell JS, Clozel J-P, Müller RKM, et al: Inhibitors of angiotensin-converting enzyme prevent myointimal proliferation after vascular injury. Science 1989; 245: 186-188.

232. Kauffmann RF, Bean JS, Zimmermann KM, Brown RF, Steinberg MI: Losartan, a nonpeptide angiotensin II (ANGII) receptor antagonist, inhibits neointima formation following balloon injury to rat carotid arteries. Life Sci 1991; 49: 223-228.

233. Daemen MJAP, Lombardi DM, Bosman FT, Schwartz SM: Angiotensin II induces smooth muscle cell proliferation in the normal and injured rat arterial wall. Circ Res 1991; 68: 450-456.

234. van Kleef EM, Smits JFM, De Mey JGR, et al: Aladrenoceptor blockade reduces the angiotensin II-induced vascular smooth muscle cell DNA synthesis in the rat thoracic aorta and carotid artery. Circ Res 1992; 70: 1122-1127.

235. Forney Prescott M, Webb RL, Reidy MA: Angiotensin-converting enzyme inhibitor versus angiotensin II, AT1 receptor antagonist. Am J Pathol 1991; 139: 1291-1296.

236. Janiak P, Pillon A, Prost J-F, Vilaine J-P: Role of angiotensin subtype 2 receptor in neointima formation after vascular injury. Hypertension 1992; 20: 737-745.

237. Bunkenburg B, van Amelsvoort T, Rogg H, Wood JM: Receptor-mediated effects of angiotensin II on growth of vascular smooth muscle cells from spontaneously hypertensive rats. Hypertension 1992; 20: 746-754.

238. Lyall F, Dornam ES, McQueen J, Boswell F, Kelly $\mathrm{M}$ : Angiotensin II increases proto-oncogene expression and phosphoinositide turnover in vascular smooth muscle cells via the angiotensin II AT1 receptor. $J$ Hypertens 1992; 10: 1463-1469.

239. Griffin SA, Brown WCB, MacPherson F, et al: Angiotensin II causes vascular hypertrophy in part by a non-pressor mechanism. Hypertension 1991; 17: 626-635.

240. Heagerty AM: Angiotensin II: Vasoconstrictor or growth factor? J Cardiovasc Pharmacol 1991; 18 (suppl 2): S14-S19.

241. Lever AF, Lyall F, Morton JJ, Folkow B: Angiotensin II, vascular structure and blood pressure. Kidney Int 1992; 41 (suppl 37): S-51-S-55.

242. Peters J, Bader M, Ganten D, Mullins J: Tissue Distribution of Ren-2 Expression in Transgenic Rats, in K. Berg VBulyzhenkov, Y. Christen, P. Corvol (ed):Genetic Approaches to Coronary Heart Disease and Hypertension. Berlin, Heidelberg, Springer Verlag, 1991, pp 74-80.

243. Bader M, Zhao Y, Sander M, et al: Role of tissue renin in the pathophysiology of hypertension in TGR (mREN2) 27 rats. Hypertension 1992; 19: 681-686.

244. Zhao Y, Bader M, Kreutz R, et al: Ontogenetic regulation of the mouse Ren-2d renin gene in transgenic hypertensive rats, TGR (mREN2)27. Am J Physiol 1993; 265: E695-E707.

245. Mullins JJ, Sigmund CD, Kane-Haas C, McGowan RA, Gross KW: Expression of the DBA/2J Ren-2 gene in the adrenal gland of trasgenic mice. EMBO J 1989; 8: 4065-4072.

246. Bachmann S, Peters J, Engler E, Ganten D, Mullins $\mathrm{J}$ : Transgenic rats carrying the mouse renin genemorphological characterization of a low renin hypertension model. Kidney Int 1992; 41: 24-36.

247. Lee M, Zhao Y, Peters J, et al: Preparation and analysis of transgenic rats expressing the mouse Ren2 gene. J Vasc Med Biol 1991; 3: 50-54.

248. Peters J, Münter K, Bader M, Hackenthal E, Mullins JJ, Ganten D: Increased adrenal renin in transgenic hypertensive rats, TGR (mREN2) 27, and its regulation by cAMP, angiotensin II, and calcium. J Clin Invest $1993 ; 91$ : 742-747.

249. Haning R, Tait SAS, Tait JF: In vitro effects of ACTH, angiotensins, serotonin and potassium on steroid output and conversion of corticosterone to aldosterone by isolated adrenal cells. Endocrinology 1970; 87: 1147-1167.

250. Aguilera G, Catt KJ: Loci of action of regulators of aldosterone biosynthesis in isolated glomerulosa cells. Endocrinology 1979; 104: 1046-1052.

251. Ryan JW: Renin-like enzyme in the adrenal gland. Science 1967; 158: 1589-1590.

252. Ganten D, Hutchinson JS, Schelling P, Ganten U, Fischer H: The iso-renin angiotensin systems in extrarenal tissue. Clin Exp Pharmacol Physiol 1976; 3: 103-126.

253. Doi Y, Atarashi K, Franco-Saenz R, Mulrow P: Adrenal renin: a possible regulator of aldosterone production. Clin Exp Hypertens [A] 1983; 5: 1119-1126.

254. Nakamaru M, Misono KS, Naruse M, Workman RJ, Inagami T: A role for the adrenal renin-angiotensin system in the regulation of potassium-stimulated aldosterone production. Endocrinology 1985; 117: 1772-1778.

255. Husain A, DeSilva P, Speth RC, Bumpus FM: Regulation of angiotensin II in rat adrenal gland. Circ Res 1987; 60: 640-648.

256. Horiba N, Nomura K, Shizume K: Exogenous and locally synthesized angiotensin II and glomerulosa cell functions. Hypertension 1990; 15: 190-197.

257. Sasamura H, Suzuki H, Kato R, Saruta T: Effects of angiotensin II, ACTH, and KCI on the adrenal renin-angiotensin system in the rat. Acta Endocrinol (Copenh) 1990; 122: 369-373.

258. Oda H, Lotshaw DP, Franco-Saenz R, Mulrow PJ: 
Local generation of angiotensin II as a mechanism of aldosterone secretion in rat adrenal capsules. Proc Soc Exp Biol Med 1991; 196: 175-177.

259. Sander M, Bader M, Djavidani B, et al: The role of the adrenal gland in the hypertensive transgenic rats TGR (mREN2)27. Endocrinology 1992; 131: 807-814.

260. Djavidani B, Sander M, Böhm M, et al: Dexamethasone suppresses development of fulminant hypertension in TGR (mREN2)27. J Hypertens 1992; 10 (suppl 4): S10. (Abstract)

261. Hilgers KF, Peters J, Veelken R, et al: Increased vascular angiotensin formation in female rats harboring the mouse Ren-2 gene. Hypertension 1992; 19: 687-691.

262. Lee M, Boehm M, Bader M, et al: High sensitivity to converting enzyme inhibition in hypertensive transgenic rats (TGR) carrying the renin gene of the mouse (ren-2). J Hypertens 1991; 9 (suppl 6): S458-S459. (Abstract)
263. Ganten D, Lee M, Sander M, Peters J, Bader M, Paul M: The renin gene in hypertension: from molecular analysis to hypertensive transgenic rats. Eur J Physiol 1991; 419 (suppl 1): R124, 307. (Abstract)

264. Fukamizu A, Takahashi S, Seo MS, et al: Structure and expression of the human angiotensinogen gene. $J$ Biol Chem 1990; 265: 7576-7582.

265. Gardes J, Bouhnik J, Clauser E, Corvol P, Ménard $\mathrm{J}$ : Role of angiotensinogen in blood pressure homeostasis. Hypertension 1982; 4: 185-189.

266. Helene C, Toulme J-J: Specific regulation of gene expression by antisense, sense and antigene nucleic acids. Biochem Biophys Acta 1990; 1049: 99-125.

267. Capecchi M: Altering the genome by homologous recombination. Science 1991; 244: 1288-1292.

268. Steinhelper ME, Cochrane KL, Field LJ: Hypotension in transgenic mice expressing atrial natriuretic factor fusion genes. Hypertension 1990; 16: 301-307. 